\title{
LOCAL WISDOM IN COFFEE CAFÉ IN MEDAN: ANTHROPOLINGUISTIC APPROACH
}

\author{
Hidayati, Arifuddin, Aflina, Zainab MZ \\ Fakultas Bahasa dan Komunikasi \\ Universitas Harapan Medan, Indonesia \\ E-mail: yatihida853@gmail.com
}

Received: 13 April 2020

Accepted: 06 June 2020

\begin{abstract}
The tradition of drinking coffee, as a cultural heritage of Indonesia, has existed for generations in the city of Medan, the capital of the province of North Sumatra and Sumatra is also a coffee-producing region in Indonesia, so it is not surprising to see the rise of coffee shop business with the current name of coffee café in Medan. Drinking coffee at the café is not just a necessity, it has become a lifestyle and is not limited to age, profession or social status; all the people gather and unite in this place and produce a togetherness. By means of Anthropolinguistic approach, the one referring to the study of humans and cultures related to linguistic functions and all the dynamics inherent in human activities, the research, aimed at revealing local wisdom in coffee cafes in the city of Medan, and based on the notion of cultural heritage preservation, is conducted using descriptive qualitative methods, revealing a series of community activities related to coffee café in Medan, supported by validity data in the form of interviews and questionnaires, with the key instruments, respondents, who truly understand the phenomenon of the tradition of drinking coffee. The results show that local wisdom is found in the coffee café in Medan, with a percentage of 96, having three points of discussion: Social Interaction Establishment through Polite Language (88\%), Cultural Heritage Preservation (96\%) and Economic Growth Improvement (92\%).
\end{abstract}

Keywords: local wisdom, polite language, cultural heritage preservation, economic growth improvement.

\section{Introduction}

Understanding and preservation of culture, in this case the diversity of cultures in Indonesia, serves as a fortress to maintain the wholeness and the existence of culture from the influence of the drastic changing of times. Socialization about culture up to the internalization stage must be done through cultural studies, so that the existing cultures in Indonesia are not easily eroded by time and space. Through a culture a person can learn about life, improve the quality of life, care about the environment, have a sense of sympathy and empathy and help each other to get a better standard of living, prosperity and peace.

Cultural studies in general are theoretical perspectives on an object through the perspectives of various fields of science, meaning cultural studies are not limited only to the studies of human activities because all forms of human knowledge are basically included in cultural studies; thus the meaning of cultural studies can be simplified as an interdisciplinary 
field that uses the views of other fields of science to examine the relationship between culture and politics, economics, society and sovereignty. The object of cultural studies is not limited to the arts or is often paired with cultural arts, but rather all forms of human activity aimed at improving the welfare of life again including physical and spiritual well-being.

Culture derives from human creations, tastes and initiatives. The scope covers many aspects of life such as law, beliefs, art, customs or habits, moral, and also expertise. Its presence is able to influence one's knowledge and ideas. This is in line with Koentjaraningrat (1993) stating that culture is the whole system of ideas, belonging to humans obtained by learning supported by seven elements: Language, Knowledge, Social Organizations, Living Equipment and Technology, Livelihoods, Belief and Arts.

This research is focused on the changing of human behavior related to cultural traditions, the phenomenon of the rise of coffee café business in the city of Medan, the capital of North Sumatra province, Indonesia, by means of anthropolinguistic approach. The study of culture in the field of anthropolinguistics means understanding the intricacies of culture from the study of language or understanding culture through language from a linguistic perspective. Other aspects of human life besides culture such as politics, religion, history, and marketing are also studied through language in the framework of anthropolinguistic studies. On that basis, anthropolinguistics not only examines language, but also culture and other aspects of human life (Sibarani: 2015). So when language politeness is studied, the focus of the study lies in the practice of language politeness; likewise, the preservation of cultural heritage and the improvement of the economy also focused on the practice or effort made by the community not to forget the past and find ways to improve the welfare.

The tradition of drinking coffee in a coffee shop with the contemporary term coffee café, is not a new thing for the people of Indonesia, especially those of Medan. This tradition is not only found in the city of Medan, but in various places outside Medan and this tradition has existed since ancient times and has become a cultural heritage. Cultural heritage is not just a monument or heirloom, but also contains traditions or expressions of life passed down from time to time such as performing arts, social practices, rituals, knowledge and skills to improve the standard of living in various lines.

In every accepted tradition, local wisdom exists. Local wisdom is an ideology or the way of life of a group of communities in the form of activities carried out by the local community to solve problems related to daily needs. Local wisdom encompasses a variety of policies based on the values of goodness that are believed to be used as guidelines for life and are always preserved. Other terms used are local knowledge and local skills or genius (Hidayati: 2018).

The research based on the Anthropolinguistic approach, is carried out to describe the local wisdom in the coffee café or the tradition of drinking coffee in the city of Medan having three points of discussion: Social Interaction Establishment through Polite Language, Cultural Heritage Preservation and Economic Growth Improvement. Descriptive qualitative research method supported by phenomenological quantities is applied, providing an understanding of the activities or changes in behavior of a group of people as well as social actions undertaken by related communities through natural observation so that a description of the cause and effect of an event can be explained appropriately (Cresswell: 2009).

\section{Literature Review}

\subsection{Cultural Heritage}

Cultural heritage is not only based on monuments, historical buildings or library objects simply because cultural heritage has a broad scope. Life management, as well as 
traditions or rituals as well as all forms of social activities to improve living standards also enter the realm of cultural heritage because basically all activities found today are flashbacks of all past activities with different versions.

Cultural heritage according to Davidson in Asfina and Ririn (2016) is concrete cultural product or woks resulted from a numbers of tradition (tangible heritage) and spiritual values from the past (intangible heritage) which become the identity of a group or a nation There are many tangible cultures such as temples, artifact, historical building and places spreading all over the country. Not only tangible cultures, Indonesia also has many intangible cultures such the songs, stories, norms and values.

However not all cultural heritage is worth preserving or revitalizing; those that can provide benefits for human life today must be preserved and generally contain local wisdom. The interrelationship between cultural heritage and local wisdom can be used as a reference to be guided.

\subsection{Local Wisdom}

Local wisdom is also passed down through generations through oral or written media and becomes an inseparable part of a community. A concept of thought that has been inherited can only be said as local wisdom if it has the ability to control, can be used as a filter and accommodate the influence of outside ideology, and has a view or concept to develop its potential.

Mindset and good behavior, love of the birth land, consistency of thought patterns and behaviors that have been inherited, are features of a local wisdom. Wisdom is not only in the form of cultural norms and values, but also in all elements of ideas that have implications for technology, handling social problems, and aesthetics. By this concept, what is included as a meaning of local wisdom is a variety of patterns of action and material cultural outcomes. This is in line with the view of Jundiani (2018) stating that local wisdom is defined as a view of life and knowledge as well as the various life strategies in the form of people's activities in answering multiple problems regarding in the fulfillment of their needs.

Then Manugeren (2017) states that local wisdom is a set of ideas or policies based on the values of virtues found in a community and often applied, believed to be the guidance of life, and handed down from time to time. Local wisdom can be in the forms of knowledge, skills and policies used for the welfare of the peoples concerned. So the scopes are local knowledge that functions to adapt to the environment; local values, serving as guidelines or rules for right or wrong actions, local skills as a source of inspiration to earn a living; local resources referring to local natural resources with proper balance; decision making mechanism, used to solve a problem; solidarity referring to togetherness.

\subsection{Social Relationship Establishment through Polite Language.}

Every human being cannot live alone because humans are social creatures who need others; therefore, it is important for every human being to establish good social relationships with others. Establishing social relationships with family, friends, relatives, neighbors and people around is a form of affection and care for others.

Another virtue of social relationship is that it can increase empathy and avoid selfishness. One is accustomed to respecting other, and listening to their stories and problems. For that reason, indirect social relationships, run consistently can form empathy and put someone away from selfish attitudes and finally making life happier and healthier. This is in line with J. Holt-Lunstad (2017) stating that social relationships are adaptive and 
crucial for survival. Social connections to others have powerful influences on health and longevity and that lacking social connection qualifies as a risk factor for premature mortality. Those who curb themselves from society can experience various health problems. From this it is clearly illustrated that building social relations is crucial in human life.

The basic thing needed to build a good social relationship is good communication through polite language. Everyone likes to communicate with people who use polite language. Language skills reflect a person's personality. Good language skills, full of politeness, portray a good and virtuous personality. Through language too, a nation will be known by the world community. Since politeness is crucial to the construction and maintenanceof social relationships, politeness in communication goes tothe very heart of social life and interaction; indeed it is probablya precondition for human cooperation in general (Brown: 2015).

\subsection{Cultural Heritage Preservation and Economic Growth Improvement.}

The advancement of science and technology is not a barrier to preserve cultural heritage; on the contrary it can be used as added value to maintain cultural heritage. Such rapid delivery of information makes it easier for everyone to provide a description of the importance of maintaining the values inherent in each of these cultural heritages. There are at least four arguments behind the preservation of heritage: (1) scientific (re-search and increased knowledge), (2) political (messages and symbolism), (3) social (sense of place and cultural identity) and (4) economic (attracts tourists and visitors to the region).Cultural heritages play a strong role in both economic and social life even though the majority remains informal, without public protection and without explicit management as they are the main institutions that connect history, territory and society, defining the cultural context of social life (Nilson and Kristina: 2018).

Each region in Indonesia has a variety of cultural heritages that characterize the life of the nation and state and at this time, due to the rapid change of age, cultural heritage is easily eroded; then each individual, community group, and government must work together to rebuild or maintain the existing cultural heritage because the values of local wisdom contained therein are very beneficial for the harmonization of life. The effort to improve the standard of living by increasing economic growth is also a value of local wisdom which in this study is related to running a coffee café business. Increasing economic growth is not absolutely the responsibility of the government because every individual is also responsible for this problem because every individual is part of the government.

When the economy is growing rapidly, all parties, the government and the community can benefit: government and community revenues will increase; poverty can be overcome well, life expectancy also increases and the education system is getting better.'Historically nothing has worked better than economic growth in enabling societies to improve the life chances of their members, including those at the very bottom (Rodrik: 2013).

\section{Research Method}

This research is conducted with a descriptive qualitative method and also supported by a phenomonological quantities, namely expressing events, and analyzing phenomena, events, social activities, attitudes of beliefs, perceptions, thoughts of people individually or in groups (Creswell: 2009), in this case related to the rise of coffee cafe business in the city of 
Medan, and subsequently producing descriptive data in the form of written or oral words from people and observed behavior (Moleong: 2011).

The locations are three coffee cafes randomly chosen as representatives of all coffee cafes in the city of Medan, supported by primary data and secondary sources. Primary data are obtained directly from the locations while secondary data from various sources such as: interviews, questionaires, random sampling and also related references. Another additional technique is observation, documentation, quick notes referring to data analysis leading to local wisdom based on interactive data analysis (Miles and Huberman: 2014).

Non-structured interviews are applied in this study meaning that 25 respondents 25 could answer all the questions freely related to the discussion of local wisdom. The respondents are academics in the fields of sociology, culture and enonomy knowing well benefits of coffee cafe business and other respondents are from among students, and community leaders. Regarding reliable validity, comparative techniques are used: data from observations with interview results; utterances in the community with those in privacy; community comments about the research situation with those outside the research situation; and the results of interviews and questioners with the contents of related documents.

\section{Results and Discussion}

Drinking coffee is no longer just drinking coffee, but has become a routine for the community. Discussing or chatting while drinking coffee is the cultural tradition of Indonesian society. At this time people come to the coffee café in the city of Medan not only to enjoy a cup of coffee, but they come to chat with each other and exchange ideas. Nowadays Indonesian people especially millennials are looking for a good place or instagramable places to take pictures and post them on social media, they are more concerned with a good and unique place than the taste of coffee drinks.

Over time, the world of coffee is growing very rapidly. People who previously only enjoy instant coffee at home are now starting to move to coffee cafes in the city of Medan and this phenomenon can be seen with the rise of the opening of coffee cafes in the city of Medan. Coffee cafés are also experiencing rapid progress. Initially the coffee shops in the city of Medan are simple, and the facilities given are only long benches and stalls usually found on the side of the streets. This is the initial phase of the coffee shop and this time, the coffee shop which is also called café is growing with the presence of contemporary facilities such as internet, television and also music and food. Coffee drinks are also of various variants such as black and cold coffee, milk coffee, espresso, and capucino.

Figure 1: coffe shop of the past

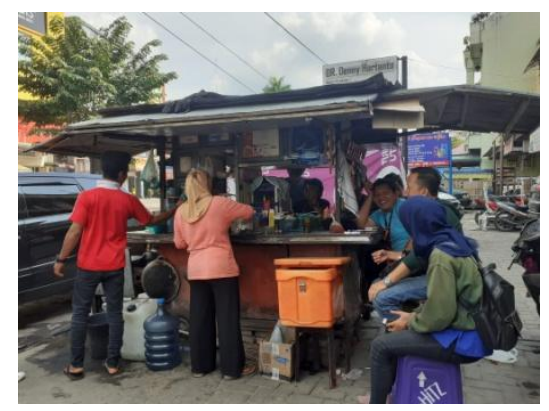

Figure 2: coffee café of the present

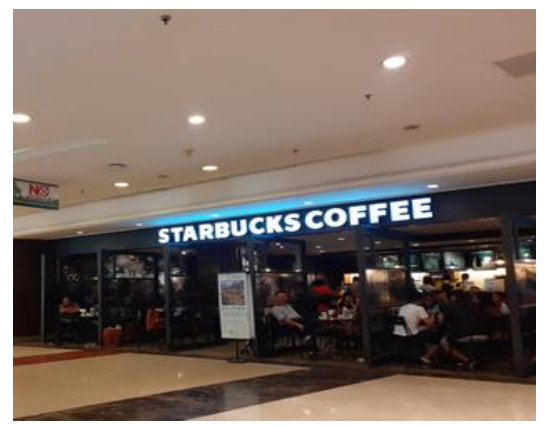




\subsection{Local Wisdom}

Local wisdom can be understood as human efforts based on the use of cognitive ability to act wisely towards the circumstances, objects, or events that occur in the local space and subsequently can be guided to a harmonious relationship, not only among humans, but also with the surrounding environments and nature. Thus it can be said that local wisdom has limited interaction space with limited values or norms, meaning that local wisdom in a community may not necessarily be applied to other communities, although it has the same goal of obtaining prosperity, harmony, and peace. This happens because the values and norms existing in the society originate from cultural inheritance. That is why local wisdom can also be said as traditional local wisdom.

Local wisdom or traditional local wisdom refers to locality because it is owned by a local community or certain community; but that does not mean that local wisdom is not universal. To say that local wisdom is not in line with modern science is only because the concept of is wrongly interpreted. Science or technological progress is always considered universal and this is a reality; however local wisdom is also universal with the premise that local wisdom is related to humans and nature, and humans and nature are universal; then without being deliberately designed local wisdom is also universal.

\subsection{Social Interaction Establishment through Polite Language.}

Coffee cafes in Medan are built with different motivations. Coffee cafe business owners build their coffee cafés as business land, or also a hobby. For coffee drinkers, the function of a coffee cafe is as a place to drink coffee and at the same time establish social relations with new people or increasing the friendly relations that have existed before. $A$ good coffee cafe is a place of diverse excitements, knowledge and learnings. A coffee cafe has a noble function, a meeting place for many people leading to friendship among them. The coffee cafe is a small universe where people meet and have exciting conversations. This is a coffee sho café, all the differences from various levels of society blended into one through this marvelous coffee. Much information is obtained the coffee cafe and so many friendships are forged.

Surely the whole friendship or social interactions in a coffee cafe must be supported by polite communication. Politeness is an important element in social life, because by showing good manners, a person can be wherever he is. In social life norms or ethics are there. Good manners could provide benefits or good influence on people. Polite means rules of life arising from the results of association with a group of people in society and are considered to be the demands of the community and then manners can also be reflected through polite language as well.

Therefore politeness in language is very important especially if someone wants to make friends in a coffee cafe. When someone meets a new person or communicates with unknown people he must use polite language so that the persons could have a kind of acceptance. Then the coffee café is a forum for polite language learning.

\subsection{Cultural Heritage Preservation}

The tradition of drinking coffee is a cultural heritage in Indonesia and this tradition is not only found in the city of Medan, but in all parts of Indonesia. Indonesia is famous for being rich in cultures. These diverse cultures arae one of the strengths which is at the same time characteristics of the Indonesian nation. One form of culture is the tradition of drinking 
coffee, which comes from the past. These culturalal heritage from the past can be a bridge to know the life of the present as well as the future.

However the process of globalization and social transformation causes the occurrence of symptoms of intolerance, also poses a serious threat that can cause deterioration, extinction and destruction of cultural heritage. The cultural heritage referred to here is various representations, expressions, skills and related instruments, objects, artifacts and cultural environments including various communities, groups, and in certain cases, individuals recognized as part of their cultural heritage.

Basically, coffee cafés entrepreneurs as well as the customers in the city of Medan have made a major contribution to the preservation of cultural heritage, namely the tradition of drinking coffee having local wisdom in the midst of the changing of times with all its knick knacks that can keep people away from their own culture. Without realizing it, people in Medan, especially millennials, have a good place to spend leisure time and at the same time get entertainment. In this way their activities can be more controlled and also prevented from going to other entertainment places of a higher risk.

\section{4 Economic Growth Improvement.}

Improving the welfare is a part of local wisdom and the usual reference given to welfare is the improvement of the economy, both of individuals and groups. When a person's life and group prosper, then they always keep themselves away from conflict, especially internal conflict because they want to live in peace and happiness. From this it can be said that the economy plays a very large role in solving social problems.

In connection with improving the economy, Indonesia as the third largest coffee producing country in the world has great potential to improve the welfare of the community if the natural resources can be managed properly, transparently and equally. The productions of Indonesian coffee is currently ranked the world's third largest. Coffee does not only provide the experience of taste but also cultural identity of Indonesia. With the climate condition in the country, coffee can grow very well (Ditjen PEN: 2014).

This illustrates that the coffee supply in Indonesia, including the regions around Medan, is quite large and can be used to run a coffee cafe business smoothly, which means that coffee café entrepreneurs in the city of Medan need not worry about the lack of coffee supply. This can also stimulate coffee farmers to produce more coffee because of the availability of buyers; besides that coffee farmers of course also need more labor and with the existence of jobs like this the community's economic level will also increase.

Coffee cafes in Medan also open employment not only to those who work directly at the cafes, but also to those who do not work directly at the coffee cafes like other food vendors selling directly at the related coffee cafes or who entrust their food at the cafes. Economic growth is the economic condition of a place during a certain period that is better or increased than the previous period based on several indicators. These indicators are the increases in income of a person or group and the number of labors bigger than the unemployed, and the reduction in poverty levels. Based on this description, the existence of coffee cafes in Medan, also contributes to economic growth.

From the description above based on data obtained in the field, it is seen that the coffee cafe in Medan has points of local wisdom having data validity as follows:

Local wisdom in the coffee café in Medan is studied using 25 samples taken randomly, sourced from respondents from four community groups: millennial generation, academicians, community leaders, and practitioners who all settle in Medan and know very 
well about the condition of the city of Medan. The research instrument used is a structured interview and questioner. The results show that there are three points of local wisdom in the coffee café in Medan. The results of the questionnaire and interview show that of the 25 samples, $96 \%$ or or 24 people agree that there is local wisdom in the coffee café in Medan, one does not give answer. Furthermore, for points of local wisdom, the results show that $88 \%$ or 22 people agree that there is a Social Interaction Establishment through Polite Language in the coffee café, three do not give answer; $96 \%$ or 24 people agree with Cultural Heritage Preservation, one does not give answer and $92 \%$ or 23 people, for Economic Growth Improvement, two do not give any answer.

\begin{tabular}{|l|c|c|c|c|}
\hline \multirow{2}{*}{\multicolumn{4}{|c|}{ Indicator }} & \multicolumn{3}{c|}{$\begin{array}{c}\text { Answer Result/Number of } \\
\text { Respondent }\end{array}$} & \multirow{2}{*}{ Percentage } \\
\cline { 2 - 5 } & Agree & Disagree & No Answer & \\
\hline Local Wisdom in Coffee Cafe & 24 & 0 & 1 & 96 \\
\hline $\begin{array}{l}\text { Social Interaction Establishment } \\
\text { through Polite Language }\end{array}$ & 22 & 0 & 3 & 88 \\
\hline Cultural Heritage Preservation & 24 & 0 & 1 & 96 \\
\hline Economic Growth Improvement & 23 & 0 & 2 & 92 \\
\hline
\end{tabular}

Thus it is illustrated that all the answers are close to $100 \%$ meaning that there is local wisdom in the form of Social Interaction Establishment through Polite Language, Cultural Heritage Preservation, and Economic Growth Improvement in coffee cafes in Medan city

\section{Conclusion}

The tradition of drinking coffee, a cultural heritage deserves to be preserved because there are points of local wisdom to be used as guidelines in carrying out and improving living standards so that eventually social problems can be resolved wisely and the community can live in peace and happiness. Through this research, with an anthropolinguistic approach, it is illustrated that the coffee cafe business which is very popular lately in Medan has three significant points of local wisdom: Social Interaction Establishment through Polite Language, Cultural Heritage Preservation and Economic Growth Improvement. Data validation of the three forms of local wisdom is supported by questionnaire and interview data collection techniques.

The locations of the research are coffee cafés chosen randomly in the city of Medan. Medan City is a multiracial city, inhabited by various ethnics having good relations with one another. This relationship is certainly based on politeness in language so that the people of Medan are easy to get along with. By tolerance, empathy and sympathy between one and other tribes, they can maintain the existing cultural heritage with mutual respect. Furthermore, individuals who inhabit multiracial areas are generally determined to earn a living with a high level of innovation and creativity to maintain their tribal prestige and these are all points of local wisdom that are also found in coffee cafes in the city of Medan. These three points of local wisdom enter the realm of language frameworks referring to the Anthropolinuistic approach. 


\section{References}

Asfina, Risa and Ririn Ovilia. (2016). Be Proud of Indonesian Cultural Heritage Richness and Be Alert of Its Preservation Efforts in the Global World. Humanus. Vol. XV, No. 2. http://ejournal.unp.ac.id/index.php/humanus/index

Barker, C. (2000). Cultural Studies: Teori dan Praktik. Terjemahan oleh Nurhadi (2004). Yogyakarta: Penerbit Kreasi Wacana.

Brown, Penelope. (2015). Politeness and Language. International Encyclopedia of the Social \& Behavioral Sciences, 2nd edition, Volume 18. Retrieved from https://pure.mpg.de/rest/items/item_1719314_10/component/file_2152013/conten $\mathrm{t}$

Creswell, John W. (2009). Research Design. Qualitative, Quantitative and Mixed Methods Approaches. Third Edition. New Delhi: Sage.

Ditjen PEN. (2014). Indonesian Coffee. Jakarta: Kementerian Perdagangan Republik Indonesia. Retrieved from http://djpen.kemendag.go.id/app_frontend/admin/docs/publication/133142105855 $0 . p d f$

Hidayati, Hidayati. (2018) Local Wisdom of Kembar Mayang in Wedding Tradition of Jawa Ethnic. Language Literacy: Journal of Linguistics, Literature and Language Teaching. Vol. 2, No. $1 . \quad$ Retrieved https://jurnal.uisu.ac.id/index.php/languageliteracy/article/view/552.

J. Holt-Lunstad. (2017). Why Social Relationships Are Important for Physical Health: A Systems Approach to Understanding and Modifying Risk and Protection. PubMed. Retrieved from https://www.ncbi.nlm.nih.gov/pubmed/29035688

Jundiani. (2018). Local Wisdom in the Environmental Protection and Management. IOP Conf. Series: Earth and Environmental Science 175 (2018). https://iopscience.iop.org/article/10.1088/1755-1315/175/1/012130/pdf

Koentjaraningrat. (1993). Kebudayaan, Mentalitas dan Pembangunan. Jakarta: Gramedia Pustaka Utama.

Miles, M. B, Huberman, A.M, dan Saldana, J. (2014). Qualitative Data Analysis, A Methods Sourcebook, Edition 3. NY: Sage Publications. Terjemahan Tjetjep Rohindi Rohidi, UIPress.

Moleong, L. J. (2011). Metodologi Penelitian Kualitatif Edisi Revisi. Bandung: PT. Remaja Rosdakarya.

Nilson, Tomas and Kristina Thorell. (2018). Cultural Heritage Preservation: The Past, the Present and the Future. Halmstad: Halmstad University Press.

Rodrik, Dani. (2013). The Past, Present, and Future of Economic Growth. Global Citizen Foundation. https://www.sss.ias.edu/files/pdfs/Rodrik/Research/GCF_Rodrikworking-paper-1_-6-24-13.pdf

Psaltis, Charis, et. al. (2015). The Importance of Social Relations for Human and Societal Development.

ResearchGate. https://www.researchgate.net/publication/279601610_The_Importance_of_Social_R elations_for_Human_and_Societal_Development

Sibarani, Robert. (2015). Pendekatan Antropolinguistik terhadap Kajian Tradisi Lisan. RETORIKA: Jurnal IImu Bahasa. Vol. 1, No. 1. ResearchGate. Retrieved from https://www.researchgate.net/publication/314463224_Pendekatan_Antropolinguisti k_Terhadap_Kajian_Tradisi_Lisan. 